\title{
A hidden household danger: Television
}

\author{
Oğuzhan Bol, M.D., ${ }^{1}$ Hüseyin Cebiçci, M.D., ${ }^{1}$ Serhat Koyuncu, M.D., ${ }^{3}$ \\ Bahadır Şarlı, M.D., ${ }^{4}$ Nurullah Günay, M.D. ${ }^{2}$
}

\begin{abstract}
${ }^{1}$ Department of Emergency Medicine, Kayseri Training and Research Hospital, Kayseri-Turkey ${ }^{2}$ Department of Emergency Medicine, Erciyes University Faculty of Medicine, Kayseri-Turkey ${ }^{3}$ Department of Emergency Medicine, Karabük University Faculty of Medicine, Karabük-Turkey ${ }^{4}$ Department of Cardiology, Kayseri Training and Research Hospital, Kayseri-Turkey
\end{abstract}

\begin{abstract}
BACKGROUND: Today, at least I television (TV) is owned in most households, and watching TV has become a significant part of daily life. Time spent in front of the TV has increased as its popularity has grown, which may pose a danger to children. The aim of the present study was to draw attention to cases of TV tip-over-related pediatric injuries.
\end{abstract}

METHODS: Cases of TV tip-over injuries of pediatric patients admitted to the Emergency Department of Kayseri Training and Research Hospital recorded between June I, 201 I and December 3I, 2013 were included. Data were prospectively collected, including age and gender of patient, part(s) of the body affected, Glasgow Coma Scale score, TV screen size and brand, and whether the patient was hospitalized in the general ward or the intensive care unit (ICU).

RESULTS: There were 53 pediatric patients enrolled in the study, including 30 males (56.6\%) and 23 females (43.4\%). Eight patients (I7\%) had a fracture somewhere in the body, whereas 45 patients $(83 \%)$ had no fracture. Of patients with a fracture, $3(2$ males, I female) were treated in the general ward and 3 (male) in the intensive care unit. One male patient died.

CONCLUSION: An increasing number of individuals present to emergency services with injuries sustained by TV toppling. Cases of injury, permanent disability, and even death associated with falling TVs suggest that awareness of the danger should be increased, as it may affect children in particular.

Keywords: Child; toppling; TV.

\section{INTRODUCTION}

Deaths related to trauma, and domestic accidents in particular, account for significant incidence of childhood mortality. ${ }^{[1]}$ Childhood trauma primarily affects toddlers and preschoolaged children. ${ }^{[2]}$ In the US, the Consumer Product Safety Commission released the top 5 hidden household hazards in 2007 and listed tip-overs as the third leading cause of morbidity and mortality. ${ }^{[3]}$ Today, almost every family owns at least I television (TV), and the majority of time at home is spent watching TV. ${ }^{[4]}$ Decreased cost and widespread availability of TVs have led to an increase in both screen size and weight. ${ }^{[5]}$

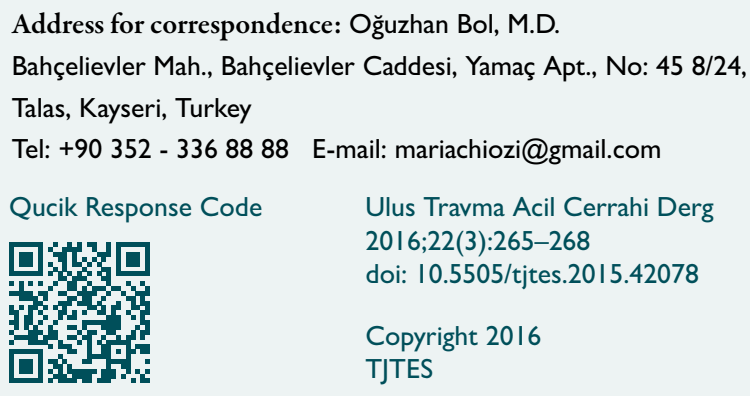

Bulkier TVs manufactured using older technology, namely the cathode ray tube (CRT), are still marketed and can be found in many households, though flat screen alternatives, including TVs with liquid crystal display (LCD) are preferred. Outmoded, large-screen CRT TVs have a high risk of falling, as their center of gravity is at the front, and most of the weight is in the screen. In addition, they are usually placed on unsecured stands, often with wheels. ${ }^{[6]}$ An increasing number of patients present with injuries caused by falling TVs. ${ }^{[7]}$ According to a report published in the US, 169 children (69\%) died from injuries caused by falling TVs between 2000 and 2010, and a rise in the number of patients rushed to emergency departments due to such injuries was observed during the decade. ${ }^{[8]}$

The present authors were surprised by the high number of patients presenting to emergency services with injuries caused by falling TVs. The present results indicate that these injuries are far more common that had been imagined. The preventable nature of these accidents and the fact that children are primarily affected contributed to the decision to conduct a comprehensive investigation. The present aim was to draw attention to incidence of accidents involving toppling TVs. 


\section{MATERIALS AND METHODS}

Cases of TV tip-over injuries sustained by pediatric patients admitted to the Emergency Department of Kayseri Training and Research Hospital recorded between June I, 20II and December 3I, 2013 were included. Conduct approval was obtained from the institutional ethics committee. Data including patient age and gender, part(s) of the body affected (divided into 3 regions including head-neck, upper extremities, and lower extremities), Glasgow Coma Scale score at presentation, TV dimension and brand, and hospitalization in the general ward or intensive care unit (ICU) were included. TV brand names are not published in the present study. Patients were evaluated by emergency care specialists and their assistants. Consultation was sought from pediatric surgery, orthopedics, and brain surgery departments when necessary. Data were analyzed using SPSS software (version 21.0; SPSS Inc., Chicago, IL, USA). Quantitative and qualitative values were expressed as mean $\pm S D$, median $(\min -\max )$ and percentage. Qualitative data were additionally analyzed using the chi-square test, and $P$ values below 0.05 were considered statistically significant.

\section{RESULTS}

A total of 53 pediatric patients were enrolled, including 30 boys (56.6\%) and 23 girls (43.4\%). Mean age of boys was 4 years (range $\mathrm{I}-10$ ), and that of girls was 3.7 years (range 2-8).
Three patients ( 2 boys, I girl; $5.7 \%$ ) sustained an injury to the head-neck region, 39 patients ( 20 boys, 19 girls; $73.6 \%$ ) sustained an injury to an upper extremity, and II patients (8 boys, 3 girls, 20.8\%) sustained an injury to a lower extremity. No significant difference in gender and injury site was found $(\mathrm{p}=0.419)($ Table I).

Eight patients (17\%) had sustained a fracture, while 45 (83\%) had not. Two of the fractures were to the skull, and 6 affected the upper extremities. A statistically significant difference was observed with regard to the absence of fractures in the lower extremities, compared to other sites of injury $(p=0.00 \mathrm{I})$. Of the patients with fractures, 7 were boys, and I was a girl. Incidence of trauma-related fractures among boys was statistically significant $(p=0.032)$ (Table 2$)$.

Size and number of TVs involved were as follows: 337 -inch TVs (5.7\%), I 4 55-inch TVs (26.4\%), 33 72-inch TVs (62.3\%), and 3 82-inch TVs (5.7\%). No significant difference was found between screen size and patient gender $(p=0.302)$ (Table 3$)$. There were 5 cases of fracture associated with 72-inch TVs, 2 with 55 -inch TVs, and I with an 82-inch TV. No statistically significant association was found between screen size and presence of fracture $(p=0.692)$.

Of patients with fracture, 3 ( 2 boys, I girl) were treated in the general ward, and 3 were treated in the ICU. One male

Table I. Injuries due to falling TVs according to gender, age groups, presence of fracture, hospitalization and Glasgow Coma Scale scores

\begin{tabular}{lccr}
\hline & Males & Females & p \\
\hline Number & $30(56.6 \%)$ & $23(43.4 \%)$ & \\
Age (years) & $4(1-10)$ & $3.7(2-8)$ & \\
Fracture $(\mathrm{n})$ & 7 & 1 & $=0.032$ \\
Hospitalization $(\mathrm{n})$ & General ward: 2 & General ward: I & $=0.178$ \\
& Intensive care unit: 3 & 15 & $=0.190$ \\
Glasgow Coma Scale scores & $14.27(3-15)$ & - & \\
Death & $\mathrm{I}$ & & \\
\hline
\end{tabular}

Table 2. Injuries due to falling TVs according to site of injury and presence of fracture

\begin{tabular}{lcccc}
\hline & Injury area & Gender (n) & $\begin{array}{c}\text { Presence of fractures at the } \\
\text { site of injury }\end{array}$ & Gender (n) \\
Head-neck region & $3(5.6 \%)$ & Male (2) & 2 & Male (I) \\
Upper extremities & $39(73.5 \%)$ & $\begin{array}{c}\text { Male (20) } \\
\text { Female (19) }\end{array}$ & 6 & Female (I) \\
Lower extremities & II (20.7\%) & $\begin{array}{c}\text { Male (8) } \\
\text { Female (3) }\end{array}$ & 0 & \\
\hline
\end{tabular}


Table 3. Size and number of TVs causing trauma and fracture

\begin{tabular}{lccccc}
\hline Size & 37 -inch & 55 -inch & 72-inch & 82-inch & P \\
\hline Number & $3(5.7 \%)$ & $14(26.4 \%)$ & $33(62.3 \%)$ & $3(5.7 \%)$ & \\
Fracture & 0 & 2 & 5 & 1 & $=0.692$ \\
\hline
\end{tabular}

Table 4. Presence of fracture according to TV brand

\begin{tabular}{lccccccc}
\hline Brand & Brand A & Brand B & Brand C & Brand D & Brand E & Brand F & Brand G \\
\hline Number & 37 & 8 & 3 & 2 & I & I & I \\
Fracture & 5 & 2 & - & 1 & - & - & - \\
\hline
\end{tabular}

patient died. Another patient was discharged and asked to return for follow-up visits. Remaining patients were discharged from the emergency department following completion of overall assessment. While all patients treated in the ICU were boys, no statistically significant difference in gender was found, based on the total number of patients $(p=0.190)$. Likewise, no statistically significant difference in gender was found with regard to admission to the general ward $(p=0.178)$. Mean Glasgow Coma Scale score was 14.27 (range 3-15) among boys and I5 (I5-15) among girls.

Seven TV brands were found to be associated with tip-overs. Brand A was the most common, with 37 TVs (69.8\%), followed by Brand B ( $n=8,15.1 \%)$, Brand C ( $n=3,5.7 \%)$, Brand $D(n=2,3.8 \%)$ and Brands $E, F$, and $G(n=I$ each, $1.9 \%)$ Five fractures were associated with Brand $A, 2$ with Brand $B$, and I with Brand D (Table 4). No statistically significant association between fractures and TV brands was found $(p=0.228)$.

\section{DISCUSSION}

TV toppling mainly affects small children and carries a high risk of injury and mortality among household accidents. Data of pediatric patients admitted to the emergency department over a period of 18 months were reviewed. Fifty-three patients were admitted with injuries sustained due to falling TVs during the study period. The authors of the present study believe that such a high number of patients presenting to a single hospital underscores the significance of these accidents among pediatric patients. DiScala et al. identified 183 such cases in a retrospective review of a 10 -year period, and Dotchin et al. identified 102 such cases that had presented over a period of 12 years. ${ }^{[9,10]}$ Authors of a report published in the US identified 12,800 emergency room visits due to such injuries in 2011 in patients aged 19 and under. $^{[8]}$

Unfortunately, TV has become an inseparable part of life. Family members spend their free time, which could be spent engaging socially, watching TV. A study conducted in Turkey found that the total percentage of people spending 2 to more than 4 hours watching TV was $90 \%$ in 1994, while the number reportedly fell to $76.4 \%$ in $2014 .^{[1,12]}$ Although a decline was observed, it is obvious that families still spend their valuable free time watching TV.

Due to the long hours spent watching TV, the area around the set is increasingly used for play, and it is unfortunate that the set sometimes becomes part of the game. As a result, accidents caused by these dangerous "toys" are increasing, and studies show that accidents related to falling TVs are on the rise. ${ }^{[13-15]}$

The present male:female ratio and mean age were comparable, with most patients aged between $\mathrm{I}-4$ years. However, the number fractures was higher among boys, possibly due to them being more physically active. Rutkoski et al. reported a male:female ratio of $\mathrm{I}: \mathrm{I}$, with a mean age of 36 months, ${ }^{[3]}$ while Gokhan et al. reported a mean age of 39 months, with a predominance of male patients (70.4\%). ${ }^{[2]}$ In a retrospective review spanning 10 years, Murray et al. found that the population affected was primarily male, and included children aged between $\mathrm{I}-4$ years. ${ }^{[6]}$

In recent years, large-screen LCD and light-emitting diode (LED) TVs have become more common. In spite of their availability, outmoded CRT TVs are still found in many households. Several physical properties of these sets increase the risk of injury from toppling. The heaviest part of a standard CRT TV is the screen. Thus, weight increases dramatically with larger screen sizes (a 72-inch CRT TV can weigh up to $50 \mathrm{~kg}$ ), and the center of gravity of the sets is based in the screen. ${ }^{[16]}$ Each of the present patients was a small child, and 55-inch and 72-inch screens were more commonly associated with injury. Güloğlu et al. and De Roo et al. reported similar findings regarding screen size, ${ }^{[1,13]}$ which may be due to the popularity of these sizes.

Given the mechanism of injury associated with falling TVs and the anatomy of children, injuries to the head and upper extremities can be expected. High placement of TVs can 
pose significantly greater risk. Although isolated head traumas were presently found to be less common than those to the upper and lower extremities, it was striking that 2 of 3 patients with head injuries had skull fractures that led to hospitalization. The head was the most common site of injury reported by DiScala et al., and Güloğlu et al. reported similar results. ${ }^{[1,10]}$

In the present study, 3 patients were treated in the general ward and 3 in the ICU. One patient treated in the ICU survived with neurologic sequelae and is still dependent. Another died in the emergency room. These figures may not be statistically significant, but real-life consequences are substantial. It is clear that we should be more aware of such preventable traumas.

\section{Conclusion}

TV has become an essential part of our daily lives, and is one of the most popular household commodities. Many families own more than I, and children spend most of their time watching TV, rather than playing games. The inclusion of the TV set in a game can have undesired consequences. It is presently recommended that TVs should be placed on more secure stands, affixed with securing tools, or, preferably, mounted on a wall. Care should be taken not to leave children in front of the TV unattended. It may be advisable to allow children to spend as little time as possible in front of the TV.

\section{Conflict of interest: None declared.}

\section{REFERENCES}

1. Güloğlu R, Sarıcı IS, Bademler S, Emirikçi S, Işsever H, Yanar H, et al. Falling television related child injuries in Turkey: 10-year experience. Ulus Travma Acil Cerrahi Derg 2012;18:61-4. Crossref
2. Gokhan S, Kose O, Ozhasenekler A, Orak M, Ustundag M, Guloglu C. Mortality and morbidity in children caused by falling televisions: a retrospective analysis of 71 cases. Int J Emerg Med 2010;3:305-8. Crossref

3. Rutkoski JD, Sippey M, Gaines BA. Traumatic television tip-overs in the pediatric patient population. J Surg Res 2011;166:199-204. Crossref

4. Suresh N, Harini G, Radhika R, Chidambaram B. Head injuries in children resulting from the fall of television. Indian J Pediatr 2010;77:459-60.

5. Jea A, Ragheb J, Morrison G. Television tipovers as a significant source of pediatric head injury. Pediatr Neurosurg 2003;38:191-4. Crossref

6. Murray KJ, Griffin R, Rue LW 3rd, McGwin G Jr. Recent trends in television tip over-related injuries among children aged 0-9 years. Inj Prev 2009;15:240-3. Crossref

7. Mills J, Grushka J, Butterworth S. Television-related injuries in childrenthe British Columbia experience. J Pediatr Surg 2012;47:991-5. Crossref

8. USA Facts: Television and Furniture Tip-Over Safety 2012 [Internet]. Available from: http://www.preventionworks-nj.org/ pdfs/2012FactSheetTVFurniture.pdf.

9. Dotchin SA, Gordon KE. The terrible truth about toppling televisions. Paediatr Child Health 2007;12:221-4.

10. DiScala C, Barthel M, Sege R. Outcomes from television sets toppling onto toddlers. Arch Pediatr Adolesc Med 2001;155:145-8. Crossref

11. T.C. Başbakanlık Aile Araştırma Kurumu Türkiyéde Televizyon Ve Aile. [Internet]. Available from: http://ailetoplum.aile.gov.tr/ data/54293ea2369dc32.

12. Türkiye Aile Yapısı Araştırması Tespitler, Öneriler. [Internet]. Available from: http://ailetoplum.aile.gov.tr/data/54292ce0369dc32358ee2a46/ taya2013trk.pdf.

13. De Roo AC, Chounthirath T, Smith GA. Television-related injuries to children in the United States, 1990-2011. Pediatrics 2013;132:267-74.

14. Scheidler MG, Shultz BL, Schall L, Vyas A, Barksdale EM Jr. Falling televisions: The hidden danger for children. J Pediatr Surg 2002;37:5725. Crossref

15. Sikron F, Glasser S, Peleg K. Children injured following TV tipovers in Israel, 1997-2003. Child Care Health Dev 2007;33:45-51. Crossref

16. Yapisal Olmayan Tehlikelerin Azaltılması. Available at: http://www.koeri.boun.edu.tr/aheb/pdf\%20dokumanlar.

\section{ORIJINAL ÇALIŞMA - ÖZET}

\section{Evdeki gizli tehlike: Televizyon}

\section{Dr. Oğuzhan Bol,, ${ }^{1}$ Dr. Hüseyin Cebiçci, ${ }^{1}$ Dr. Serhat Koyuncu, ${ }^{3}$ Dr. Bahadır Şarlı, ${ }^{4}$ Dr. Nurullah Günay ${ }^{2}$}

${ }^{1}$ Kayseri Eğitim ve Araştırma Hastanesi, Acil Tıp Kliniği, Kayseri

${ }^{2}$ Erciyes Üniversitesi Tıp Fakültesi, Acil Tıp Anabilim Dalı, Kayseri

${ }^{3}$ Karabük Üniversitesi Tıp Fakültesi, Acil Tıp Anabilim Dalı, Karabük

${ }^{4}$ Kayseri Eğitim ve Araştırma Hastanesi, Kardiyoloji Kliniği, Kayseri

AMAÇ: Her evde en az bir tane bulunan televizyonlar günlük hayatın önemli bir parçası olmuştur. Televizyon karşısında geçirilen vakit artmıştır. Televizyon boyutları ve ağılıkları artmışır. Bu durum ise evlerde çocuklar için başka bir tehlikeyi ortaya çıkarmıştır. Amacımız üzerine televizyon düşmesi olgularına dikkat çekmektir.

GEREÇ VE YÖNTEM: 01.06.20II ile 31.12.2013 yılları arasında Kayseri Eğitim ve Araştırma Hastanesi Acil Servisi'ne gelen üzerine televizyon düşme olguları kayıt altına alındı. Hastaların yaş, cinsiyet, travmadan etkilenen bölgeleri, Glaskow koma skala değerleri, düşen televizyon boyutu, markası, servis veya yoğun bakım yatışlarının olup olmadığı ve yatış oldu ise kaç gün olduğu kayıt altına alındı.

BULGULAR: Çalışmaya alınan 53 olgunun 30'u erkek (\%56.6) ve 23'ü kadındı (\%43.4). Sekiz hastanın vücudun herhangi bir yerinde kırık var idi. Bu hastaların üçü (erkek) yoğun bakımda, üçü (iki erkek, bir kadın) ise genel serviste takip edilmişlerdir.

TARTIŞMA: Acil servislere başvuran üzerine televizyon düşme sayıları son zamanlarda giderek artmaktadır. Yaralanmaların yanı sıra sakatlanma hatta ölümlerin görülmesi çocuklarımızın evde karşılaşabilecekleri tehlikeler konusunda dikkatli olmamızı gerektirmektedir.

Anahtar sözcükler: Çocuk; düşme; televizyon. 